\title{
INTERACTION OF STOKES' EDGE WAVES WITH NEAR-SHORE ICE FORMATION
}

\author{
By Richard P. Shaw and Ralph R. Rumer \\ (Department of Civil Engineering, State University of New York at Buffalo, Buffalo, New York 14260, U.S.A.)
}

ABstract. The interaction of Stokes' edge waves with a developing near-shore ice zone is examined from two points of view. First, the effect of a well-fragmented ice suspension on the classical Stokes' edge wave is discussed. Secondly, the possibility that ice-cusp formation (and, thereafter, ice mounds or volcanoes) can be initiated by edge waves is examined. Results indicate a negligible effect of a well-fragmented floating ice field on the Stokes' dispersion equation for typical wave periods, but do indicate that the presence of a standing Stokes' edge wave may lead to the initiation of ice-field cusps as ice formation occurs in the near-shore zone.

RÉsumé. Interaction de l'onde côtière de Stokes avec la glace se formant à proximité du rivage. L'interaction des ondes de Stokes côtières avec la formation de la glace près des rivages est envisagée sous deux aspects. On étudie d'une part l'influence d'une suspension de fragments de glace sur les classiques ondes de Stokes côtières et d'autre part la possibilité que les bancs de glace et plus tard les monticules de glace ou volcans puissent tirer leur origine des ondes côtières. Ces résultats montrent que l'effet d'un champ de glaces très frag-

\section{INTRODUCTION}

Martin and Kauffman (1981) have discussed the interaction of deep water waves and newly forming ice suspensions in ocean leads and polynyas. In the early stages of the ice season in lakes, the interaction of wind-driven waves and ice suspensions is frequently relegated to the near-shore zone where accelerated cooling is possible due to the shallow depths. The formation and growth of grease ice, as described by Martin and Kauffman, will be altered in this zone by the interaction of the progressive waves and the nearshore bathymetry. This paper examines the special situation of the interaction of a standing Stokes' edge wave with a newly forming near-shore ice field. Two aspects of this possible interaction are considered: the influence of a floating ice suspension on Stokes' edge waves and the influence of Stokes' edge waves on a floating ice suspension. The inquiry into this interaction was motivated by the possibility of the observed spatial regularity of ice-mound (volcano) features being related to the presence of standing edge waves. Fahnestock and others (1973) have described the characteristics of these ice volcanoes as found in Lake Erie near Dunkirk, New York.

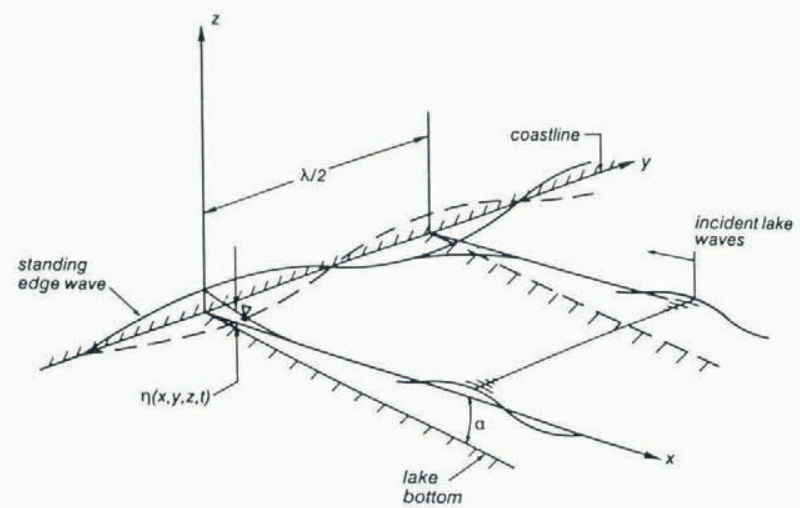

Fig. 1. Schematic sketch depicting coastine and wave systems. mentées a une influence négligeable sur l'équation de la dispersion de Stokes pour les longueurs d'ondes généralement observées, mais que la présence d'onde de Stokes côtières stationnaires peut conduire à l'apparition de bancs de glace lorsque la mer gèle près de la côte.

Zusammenfassung. Wechselwirkung zwischen Stokes'schen Kantenwellen und küstennaher Eisbildung. Die Wechselwirkung zwischen Stokes'schen Kantenwellen mit einer sich bildenden küstennahen Eiszone wird unter zwei Gesichtspunkten geprüft. Zuerst wird die Wirkung einer gut aufgelösten Eissuspension auf die klassische Stokes'sche Kantenwelle diskutiert. Dann wird die Möglichkeit der Bildung von Eis-Spitzen (und darnach von EisWällen oder-Vulkanen), ausgelöst durch Kantenwellen, untersucht. Die Ergebnisse erweisen eine vernachlässigbare Wirkung eines gut aufgelösten schwimmenden Eisfeldes auf Stokes' Dispersionsgleichung für typische Wellenperioden; doch zeigen sie andrerseits, dass das Vorhandensein einer stehenden Stokes'schen Kantenwelle zur Auslösung von Eisfeldspitzen führen kann, wenn die Eisbildung in der küstennahen Zone erfolgt.

EFFECT OF A FLOATING ICE SUSPENSION ON STOKES' EDGE WAVES

The classical Stokes' edge-wave solution has been known for many years (e.g. Stokes, 1846). It represents a wave trapped on a linearly sloping shore bounded by an infinite straight coastline (see Fig. 1). It is of interest to note that the presence of a floating ice suspension produces only minor changes in the original Stokes' solution. Only the inertial resistance of the floating ice suspension is considered here. Other mechanisms such as energy loss due to viscous effects, gelation due to sintering of ice particles, etc., would be expected to have a smaller influence on the dispersion equation than that due to inertial resistance and are not included.

The governing equation, expressed in terms of the velocity potential, $\phi(x, y, z, t)$, for a perfect fluid, is the Laplace equation

$$
\begin{aligned}
\nabla^{2} \phi & =0 \text {; for } 0<x<\infty,-\infty<y<\infty, \\
& -x \tan a<z<0,-\infty<t<\infty .
\end{aligned}
$$

On the lower surface, $z=-x \tan \alpha$ where $\alpha$ is the bottom slope angle, the requirement of zero normal velocity gives

$$
\partial \phi / \partial n=0=(\cos \alpha) \partial \phi / \partial y+(\sin \alpha) \partial \phi / \partial x ;
$$

while on the upper surface, linearized to $z=0$,

$$
\begin{aligned}
& \partial \phi / \partial z=\partial n / \partial t, \\
& \rho_{j} c h\left(\partial^{2} n / \partial t^{2}\right)=\rho_{f}(\partial \phi / \partial t+g n) .
\end{aligned}
$$

Here, $n$ is the vertical displacement of the upper surface, both for the ice and the water, $\rho_{j}$ and $\rho f$ are the ice and water mass densities respectively, and $h$ is the average thickness of the ice suspension with volume concentration $c$. The "mass loading" of the ice suspension is $\rho_{i}$ ch, (Weitz and Keller, 1950).

A solution for $\phi$ is assumed in the form

$$
\phi(x, y, z, t)=F(z) \exp (-\beta x) \exp [i(K y-\omega t)]
$$


where $B$ is the of $f$-shore wave decay parameter, $K$ is an along-shore wave number, and $\omega$ is the frequency of this assumed time-harmonic problem. Equation (1) then provides

$F(z)=A \exp (m z)+B \exp (-m z) ; m^{2}=K^{2}-B^{2}$.

The lower boundary condition requires

$$
\begin{aligned}
& B=0, \\
& m \cos \alpha=\beta \sin \alpha,
\end{aligned}
$$

for potential functions which decrease with depth (Lamb, 1932) leaving

$\phi=A \exp [K(z \sin \alpha-x \cos \alpha)] \exp [i(K y-\omega t)]$.

The upper boundary conditions require

$$
\begin{aligned}
-i \omega n= & (A K \sin \alpha) \exp (-K x \cos \alpha) x \\
& x \exp [i(K y-\omega t)], \\
(\rho f g- & \left.\omega^{2} \rho j c h\right)=i \omega \rho f A \exp (-K x \cos \alpha) \times \\
& x \exp [i(K y-\omega t)],
\end{aligned}
$$

providing a dispersion equation

$$
\omega^{2}=K g \sin \alpha /\left[1+K \sin \alpha\left(\rho_{i} c h / \rho_{f}\right)\right]
$$

which reduces to the well-known Stokes' solution if either $h$ or $c$ is zero. Introducing $\omega_{0}=(K g \sin \alpha)^{\frac{1}{2}}$ as the original stokes frequency, the frequency as modified by the ice suspension is

$$
\omega / \omega_{0}=\left[1_{0}+\omega^{2}\left(\rho_{j} c h / g_{f}\right)\right]^{\frac{1}{2}} \text {. }
$$

Martin and Kauffman (1981) have shown that the thickness of a grease-ice suspension being herded by progressive incident deep-water waves depends on the incident wave amplitude, the incident wave number, and the volume concentration of the ice suspension. Values of $c=18 \%$ to $22 \%$ were reported for the leading edge of grease-ice slicks. For incident wavelengths of approximately $280 \mathrm{ft}(85.3 \mathrm{~m})$ and wave amplitudes of $2 \mathrm{ft}(0.61 \mathrm{~m})$, the thickness of the ice suspension would be on the order of $1 \mathrm{ft}(0.3 \mathrm{~m})$. These incident wave characteristics are typical for Lake Erie during the early stages of the ice season (Resio and Vincent, 1976). Under these circumstances, the Stokes' wave frequency is only negligibly affected. In fact, the Stokes' wave frequency is changed very little over the range of wavelengths and amplitudes typical of Lake Erie. It is concluded that a floating grease-ice suspension has a negligible effect on the Stokes' edge-wave dispersion equation.

\section{ICE-CUSP FORMATION BY STANDING STOKES' EDGE WAVES}

The near-shore ice features called "ice volcanoes", as described by Fahnestock and others (1973), are shown in Figure 2. The observed mounds were periodic, spaced approximateiy $45 \mathrm{ft}(15 \mathrm{~m})$ apart and occurred in early January with winds from the west and north-west, producing lake waves essentially normal to the coastline at that location. The celerity of the incident lake waves was observed to be approximately $40 \mathrm{ft}$ per second $(14 \mathrm{~m} / \mathrm{s})$. After some time, usually overnight, the appearance of small ice volcanoes, regularly spaced, was noted. The volcanic features grow in size by expulsion of water upward through a central cavity. The expelled water freezes to the sloping sides of the mound. Cones have been observed to reach heights of $15 \mathrm{ft}(5 \mathrm{~m})$. As can be seen in Figure 2, the ice volcano features are accompanied by a cusp-like configuration of the leading edge of the shore-fast ice.

The question as to how these volcanoes and the

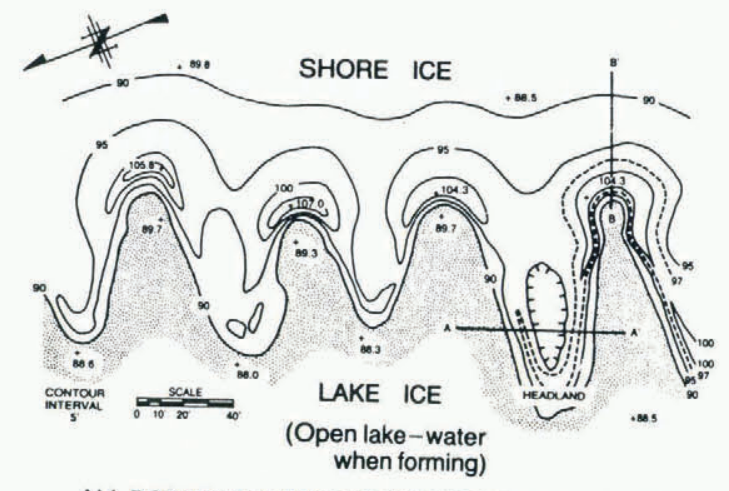

ALL POINTS RELATIVE TO ARBITRARY DATUM OF 99.99 FEET $(30.47 \mathrm{~m})$

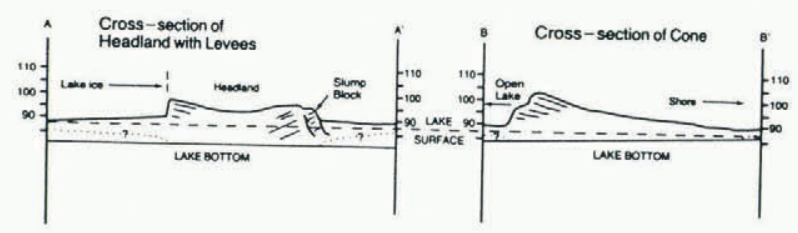

Fig. 2. Map and cross-sections of Lake Erie ice volcanoes (from Fahnestock and others (1973)).

cusp-like configuration of the ice edge may originate leads to speculation on the role of a standing edge wave in this region. The presence of a standing edge wave during the early stages of a newly forming ice field could provide the mechanism for initiation of cusping of a floating ice suspension. Although such an ice suspension may not appreciably affect edgewave frequencies as suggested in the previous section, the Eonverse may not be true.

A standing edge wave would cause alternating regions of small and of substantial wave action. A standing Stokes' edge wave of wavelength $90 \mathrm{ft}(30 \mathrm{~m})$ would require wave periods of $T=\sqrt{4.2 / \sin \alpha}$ seconds. The local lake topography near Dunkirk has a relatively straight section of shoreline oriented in a north-east direction bounded to the north-east by a promontory, Point Gratiot, and to the south-west by an under-water ridge and another promontory, Van Buren Point. Thus, a standing edge wave does appear to be possible in this region. Bottom slopes of about 3 to $5 \mathrm{deg}$, which are typical for this region, would require edge-wave periods of 14 to $18 \mathrm{~s}$. A standing Stokes' edge wave can be generated as a subharmonic (of half frequency) of incoming lake waves normally incident upon a straight coastîne (Guza and Davis, 1974; Guza and Bowen, 1976). In this case, this would require lake waves of period 7 to $9 \mathrm{~s}$. Such wave periods are typical for early winter storms on Lake Erie (Resio and Vincent, 1976).

Thus, a possible scenario for the development of a standing Stokes' edge wave and the formation of cusps in a newly-forming floating ice suspension involves a normally incident lake wave field with significant energy in the wave period range of 7 to 9 s. The standing edge wave would move the floating ice suspension on- and off-shore at locations of maximum velocity $u=\partial \phi / \partial x$. These locations would also correspond to maximum vertical displacements. Such motion might inhibit the thickening of the grease ice into dead zones (Martin and Kauffman, 1981) which congeal into shore-fast ice. One half wavelength away these motions would be zero, although there would be maximum along-shore velocity there. This sorting of the floating ice suspension by the standing edge wave could be the mechanism that causes the initiation of a cusp-like configuration to the leading edge of the developing ice field. 
Once cusps were established, the incident lake waves could act to maintain the development of cusping by a concentration of wave energy in the narrowing channels as discussed by Fahnestock and others, (1973). The effects of the edge wave are felt only near to the shore due to their exponential decay lakeward. For the parameters given here, the e-folding length is about $15 \mathrm{ft}(5 \mathrm{~m})$. However, as the shorefast ice develops, the effective shoreline location moves lakeward as well, allowing the region of influence of the edge waves to move lakeward. Edge waves can exist along a vertical wall or other topographies as well as a linearly sloping bottom, but require more complicated mathematical descriptions. The Stokes' solution is used as a simple illustration, rather than a unique situation.

\section{CONCLUSIONS}

The above discussion establishes neither the existence of standing edge waves in Lake Erie nor any definite cause-and-effect relationship between edge waves and ice cusps. However, the plausibility of such a relationship has been shown. The analogy of ice cusp formation and that of beach cusps as discussed by Guza and Inman (1975) is apparent. This phenomenon may be the winter counterpart to beach cusps which, due to the nature of the bottom sediments in this region, cannot be developed as readily as for sandy beaches. The ice volcano features may be seen as a possible indicator of the presence of edge waves which are quite difficult to measure close to shore. The initiation of a cusp-like configuration to the ice edge may be caused by a standing edge wave, but the maintenance mechanism for growth of ice mounds or volcanoes may be unrelated to the edge wave. It seems more likely that the growth of the ice mounds is maintained by ordinary on-shore lake waves as has been suggested for beach cusps by Dean and Maurmeyer (1980) and Inman and Guza (1982) as a "swash" mechanism.

The proposed mechanism for the formation of ice cusps, and eventually ice volcanoes, needs to be evaluated in the light of field data dealing with similar ice features along other shorelines. A field investigation is planned at the Dunkirk site during the 1983-84 ice season aimed at documenting more carefully the conditions that are present when these ice features are formed. It was decided to submit this preliminary theoretical development for publication in the hope that others may join in the study at different geographical locations to broaden the base of data, since this appears to be a wide-spread phenomenon.

\section{ACKNOWLEDGEMENT}

This study has been supported as part of a project entitled "Nearshore ice dynamics" which is funded by the New York State Sea Grant Institute.

\section{REFERENCES}

Dean, R.G., and Maurmeyer, E.M. 1980. Beach cusps at Point Reyes and Drakes Bay beaches, California. (In Proceedings of the seventeenth Coastal Engineering Conference, March 23 to 28, 1980, Sydney, Australia. New York, American Society of Civil Engineers, Vol. 1 , p. 863-86.)

Fahnestock, R.K., and others. 1973. Ice volcanoes of the Lake Erie shore, near Dunkirk, New York, U.S.A., by R.K. Fahnestock, D.J. Crowley, M. Wilson, and H. Schneider. Joumal of Glaciology, Vol. 12, No. 64, p. 93-99.

Guza, R.T., and Bowen, A.J. 1976. Finite amplitude edge waves. Joumal of Marine Research, Vol. 34, No. 2, p. 269-93.

Guza, R.T., and Davis, R.E. 1974. Excitation of edge waves incident on a beach. Joumal of Geophysical Research, Vol. 79, No. 9, p. 1285-91.

Guza, R.T., and Inman, D.L. 1975. Edge waves and beach cusps. Jownal of Geophysical Research, Vol. 80, No. 21 , p. 2997-3012.

Inman, D.L., and Guza, R.T. 1982. The origin of swash cusps on beaches. Marine Geology, Vol. 49, Nos. 1-2, p. $133-48$

Lamb, H. 1932. Hydrodynamics. Sixth edition. Cambridge, Cambridge University Press. [Reprinted New York, Dover Publications, 1945.]

Martin, S., and Kauffman, P. 1981. A field and laboratory study of wave damping by grease ice. Jownal of Glaciology, Vol. 27, No. 96, p. 283-313.

Resio, D.T., and Vincent, C.L. 1976. Design wave information for the Great Lakes. Report 1. Lake Erie. U.S. Army. Engineer Waterways Experiment Station. Hydraulics Laboratory. Technical Report H-76-1.

Stokes, G.G. 1846. Report on recent researches in hydrodynamics. Report of the 16th meeting, British Association for the Advancement of Science, Southampton. London, John Murray, p. 1-20.

Weitz, M., and Keller, J.B. 1950. Reflection of water waves from floating ice in water of finite depth. Comminications on Puse and Applied Mathematics, Vo1. 3, No. 3, p. 306-18. 